\title{
Starvation yields a drastic decrease in outer- membrane permeability to a periplasmic foreign protein in Myxococcus xanthus
}

\author{
Karine Laval-Favre, Barbara Letouvet-Pawlak, Sylvie Barray and \\ Janine F. Guespin-Michel
}

Equipe de Génétique Bactérienne, URA 203 CNRS, Faculté des Sciences de Rouen, 76821 MontSaint-Aignan Cedex, France

\author{
Author for correspondence: Barbara Letouvet-Pawlak. Tel: +33 351467 78. Fax: +33 35147020 . \\ e-mail: pawlak@coloris.univ-rouen.fr
}

\begin{abstract}
A recombinant Myxococcus xanthus strain was constructed that constitutively produces two proteins from Escherichia coli, the cytoplasmic $\beta$-galactosidase and the periplasmic pH 2.5 acid phosphatase (AppA protein). We have previously shown that during vegetative growth, AppA protein is partly accumulated in the periplasm of $M$. xanthus and partly released into the medium. We demonstrate here that during starvation-induced development, release of periplasmic AppA protein to the medium did not occur over a period of $20 \mathrm{~h}$. This was coincident with, but not caused by, the arrest of the synthesis of the foreign proteins. We have shown that this lack of secretion could be attributed to starvation per se and did not depend on the ability of the cells to undergo development. Our findings suggest that protein secretion which occurs during the first hours of starvation-induced development might therefore take place via a different route from that which occurs in vegetative cells.
\end{abstract}

Keywords: Myxococcus xanthus, starvation, protein secretion, outer-membrane permeability

\section{INTRODUCTION}

Protein secretion by Gram-negative bacteria is a subject of growing interest, and numerous studies have led to the discovery that protein secretion by these bacteria occurs by only a limited number of routes, as judged by homologies between the proteins that constitute secretion apparatuses (for reviews, see Pugsley, 1993; Salmond \& Reeves, 1993).

Myxococcus xantbus, however, seems to possess yet another mechanism, possibly related to the great number of proteins that this scavenging bacterium secretes during growth in order to feed upon macromolecules (GuespinMichel et al., 1993). One of the main differences between this secretory mechanism and the other known mechanisms is its lack of specificity. Thus, the four extracellular pectate lyases from Erwinia chrysanthemi are readily secreted by M. xanthus (Breton et al., 1986), whereas they are scarcely, if at all, secreted by the related species Erwinia carotovora (He et al., 1991). Even proteins that remain periplasmic in their host, such as the TEM- $2 \beta$-lactamase or the Eschericbia coli pH 2.5 acid phosphatase (AppA protein), are partly secreted when the corresponding genes are cloned into $M$. xantbus (Breton \& GuespinMichel, 1987). The remaining cell-bound activity was located in the periplasm (Letouvet-Pawlak et al., 1993). This property allowed these authors to measure the timecourse of accumulation of AppA protein in the periplasm of a recombinant $M$. xantbus strain and of it's subsequent secretion in the medium. This assay revealed that this foreign protein, synthesized as a precursor with a signal peptide (Dassa et al., 1990), is rapidly accumulated in the periplasm, then slowly released by diffusion through the outer envelope (periplasm and outer membrane). The introduction of a mutation leading to a phenotype designated $\mathrm{Exc}^{+/-}$into the recombinant strain suggested that the mechanism of secretion of this foreign protein is, at least in part, common to that of native proteins during vegetative growth. This mutation decreases the production of extracellular native proteins twofold with no evidence of protein accumulation inside the cells (Nicaud et al., 1984; Petit et al., 1993). It also decreases both the permeability of the outer membrane to AppA protein and the amount of AppA protein in the periplasm of the 
recombinant strain (Breton \& Guespin-Michel, 1987; Letouvet-Pawlak et al., 1993).

When $M$. xanthus cells are starved, a multicellular developmental cycle is induced (Kaiser, 1989; Shimkets, 1990), during which several proteins, produced rather early after starvation, are secreted, some of which display a role in cell to cell signalling (Guespin-Michel et al., 1993). In addition, all the $\mathrm{Exc}^{+/-}$mutants isolated so far and belonging to five different loci of the $M$. xanthus chromosome are unable to undergo development, which suggests a relationship between protein secretion and development (Petit et al., 1993).

In this study, we have examined the ability of the foreign AppA protein to be produced and secreted during the developmental cycle. We show that the permeability of the outer membrane to this protein is drastically altered upon starvation. This finding suggests that the mechanism of secretion during the developmental cycle might be, at least in part, different from that of vegetative cells.

\section{METHODS}

Bacterial strains, plasmids and phage. These are listed in Table 1.

Media. M. xanthus was grown in CTT medium at $30^{\circ} \mathrm{C}$ (Bretscher \& Kaiser, 1978). Escherichia coli was grown in LB medium (Miller, 1972) at $37^{\circ} \mathrm{C}$. Media were solidified with $1 \cdot 2 \%(\mathrm{w} / \mathrm{v})$ agar when necessary.

Submerged development was performed as described by Kuspa \& Kaiser (1989) with a slight modification. Late-exponential cells were centrifuged and resuspended in MC7 buffer $(10 \mathrm{mM}$ MOPS, pH 6.8, supplemented with $1 \mathrm{mM} \mathrm{CaCl}_{2}$ ) (Kuner \& Kaiser, 1982) and layered in $55 \mathrm{~mm}$ diameter Petri dishes at a density of $2-3 \times 10^{8}$ cells $\mathrm{cm}^{-2}$. At different intervais, the cells were scraped, centrifuged and activities were assayed in the supernatant and in the pellet.

Starvation experiments were performed by resuspending exponentially growing cells in different buffers (MC7 buffer or $0.01 \mathrm{M}$ Tris $/ \mathrm{HCl} / 0.001 \mathrm{M}$ potassium phosphate buffer $/ 1 \%$ $\mathrm{MgSO}_{4}, \mathrm{pH} 7 \cdot 6$, with or without added $1 \mathrm{mM} \mathrm{CaCl}_{2}$ ) at a cell density of $5 \times 10^{8}-1.25 \times 10^{9}$ cells ml ${ }^{-1}$ and agitated at $30^{\circ} \mathrm{C}$.

Plasmid construction and cloning. T4 DNA ligase and restriction enzymes were obtained from Boehringer Mannheim Biochemicals. All enzymes were used according to the specifications of the manufacturer. The ligation was performed overnight at room temperature. For the construction of plasmid pGM594, we isolated the fragments corresponding to inserts and vectors after migration of the digested plasmids on low melting point agarose gel (BRL). DNA fragments were extracted from the agarose using the Bio101 'gene-clean' kit (Ozyme). Plasmid DNA was isolated from host bacteria according to Holmes \& Quigley (1981). Transformations were performed using calcium chloride as described by Dagert \& Ehrlich (1974). Cells used in transformations (strain $\mathrm{DH} 5 \alpha \mathrm{MCR}$ ) were diluted into $1 \mathrm{ml} \mathrm{LB}$ medium after heat shock and grown for $1 \mathrm{~h}$ at $37^{\circ} \mathrm{C}$ before being plated onto selective medium containing either kanamycin $\left(50 \mu \mathrm{g} \mathrm{ml}^{-1}\right)$ or ampicillin $\left(100 \mu \mathrm{g} \mathrm{m}^{-1}\right)$, depending on the vector used (pDAH328 or pUC-4K).

Specialized transduction of plasmids from $E$. coli to $M$. xanthus using coliphage P1. This was performed according to

Table 1. Strains, plasmids and phage

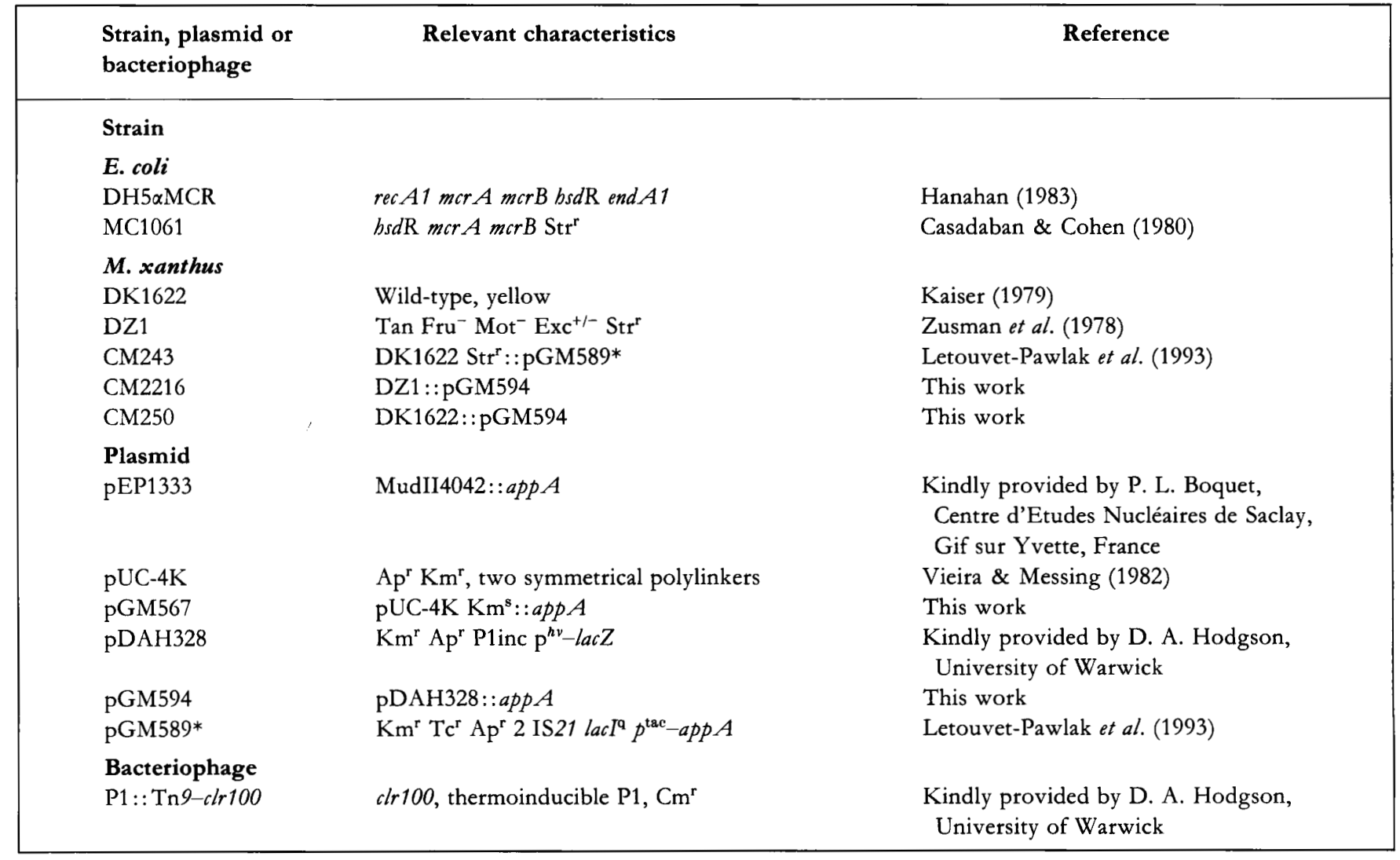


Hodgson (1987), modified from Shimkets et al. (1983). The E. coli strain used as donor was MC1061. M. xantbus transductants were selected for their resistance to kanamycin $\left(75 \mu \mathrm{g} \mathrm{ml}^{-1}\right)$.

Enzyme assays. Cells and supernatant were separated by centrifugation for $5 \mathrm{~min}$ in a microfuge.

(i) $\mathrm{pH} 2.5$ acid phosphatase. The assays were performed according to Dassa \& Boquet (1981) with p-nitrophenyl phosphate (PNPP) as substrate. One unit corresponds to the amount of enzyme that produces $1 \mathrm{nmol} p$-nitrophenol (PNP) $\min ^{-1}$ at $37^{\circ} \mathrm{C}, \mathrm{pH} 2 \cdot 5$. The molar extinction coefficient of PNP, measured under the conditions defined above, is $1.78 \times 10^{4} \mathrm{M}^{-1} \mathrm{~cm}^{-1}$ at $410 \mathrm{~nm}$ (the spontaneous hydrolysis of PNPP was routinely assayed and subtracted from our values).

(ii) $\beta$-Galactosidase. The assays were performed on cells and supernatant by the slightly modified procedure of Miller (1972) using ONPG. Cell lysis was obtained by sonication (Bioblock Scientific) in ice for a total of $45 \mathrm{~s}$ in three pulses of $15 \mathrm{~s}$ each or by addition of $100 \mathrm{mM}$ toluene, and cell debris was removed by centrifugation in a microfuge for $1 \mathrm{~min}$. One unit of $\beta$ galactosidase was defined as the amount of enzyme producing $1 \mathrm{nmol} 0$-nitrophenol $\mathrm{min}^{-1}$ at $28^{\circ} \mathrm{C}, \mathrm{pH} 7$.

(iii) Proteolytic activity. The total proteolytic activity was assayed at $\mathrm{pH} 9 \cdot 6$, or $\mathrm{pH} 6 \cdot 8$, with azocasein as substrate; one unit is defined as the amount of enzyme that hydrolyses $1 \mathrm{mg}$ azocasein in $30 \mathrm{~min}$ at $37^{\circ} \mathrm{C}$ (Millet, 1970).

(iv) Milk-clotting protease (MCP) activity. Cells were harvested by centrifugation for $5 \mathrm{~min}$ at $7000 \mathrm{~g}$ and MCP activity (Petit \& Guespin-Michel, 1992) was estimated by determining the time required for $300 \mu \mathrm{l}$ culture supernatant to induce clotting of $700 \mu \mathrm{l}$ purified $\mathrm{K}$-casein (Sigma) $\left(5 \mathrm{mg} \mathrm{ml}^{-1}\right.$ in $0.1 \mathrm{M}$ potassium phosphate buffer, $\mathrm{pH} \mathrm{6)}$ at $56^{\circ} \mathrm{C}$. Units of activity were determined as described by Douillard \& Ribadeau-Dumas (1970): the clotting time was converted into units by reference to a standard curve, $\log$ (clotting time $)=f(\log 1 /$ dilution $)$, previously established with purified rennin (EC 3.4.23.4) from calf stomach (Sigma) under the same experimental conditions. In this case, a clotting time of $1 \mathrm{~min}$ corresponds to $28.6 \mathrm{mU} \mathrm{ml}^{-1}$. It has been shown that under these conditions, other proteolytic activities from the growth supernatant of $M$. xanthus are partially inhibited (Masson \& Guespin-Michel, 1988).

\section{RESULTS}

\section{Construction of double recombinant $M$. xanthus strains expressing appA and lacZ genes}

We have previously shown (Letouvet-Pawlak et al., 1990) that the native light-inducible $b v$ promoter (Hodgson, 1987,1993 ) (previously called $\mathrm{p}^{\text {carQRS }}$ ) allowed an efficient light inducible expression of the lac $Z$ gene in $M$. xanthus. We were able to clone the $a p p A$ gene downstream of $\mathrm{p}^{h v}$ in plasmid pDAH328 (Fig. 1) and to transfer this construction from $E$. coli to $M$. xanthus by $\mathrm{P} 1$ transduction. This recombinant plasmid, pGM594, harbouring both the $a p p A$ and $l a c Z$ genes, was integrated in the chromosome of strains DZ1 (CM2216) and DK1622 (CM250) through the $\mathrm{p}^{h v}$ homologous region. However, both recombinant strains constitutively produce $\mathrm{pH} 2.5$ acid phosphatase and $\beta$-galactosidase during vegetative growth; this loss of light-inducibility could be explained either by a modification of the $\mathrm{p}^{h^{h v}}$ which would become constitutive, or by the presence of a number of transcription terminators in the region extending between the $b v$ promoter and the $a p p A$ promoter (i.e. in the Bam HI-StuI fragment from pEP1333) (Fig. 1). Nevertheless, we were unable to obtain a stable recombinant plasmid with a smaller fragment containing the appA gene (StuI-BglII fragment from $\mathrm{pEP} 1333$, for instance). However, even if the foreign genes are expressed from the E. coli app $A$ promoter, their expression in $M$. xantbus is high enough for further utilization.

The presence of the integrated pGM594 plasmid had an effect on the growth rate of strains CM2216 and CM250 (the generation time increased from $4.5 \mathrm{~h}$ to $12 \mathrm{~h}$ ), but the production of extracellular proteins during vegetative growth was not significantly altered in both strains as compared with their respective parental strain. In addition, strain CM250 retained the ability to undergo submerged development, although the timing was somewhat slower: the spores started to be produced around $30 \mathrm{~h}$ after the onset of starvation (as compared with $20 \mathrm{~h}$ in wild-type strain DK1622) and the secretion of the MCP, a developmentally regulated protein which presents a peak of production in DK1622 around $9 \mathrm{~h}$ after starvation in submerged development (Petit \& GuespinMichel, 1992), was detected only towards $15 \mathrm{~h}$ in CM250 (shown later). It was therefore possible to use strain CM250 to study membrane permeability towards AppA protein during the developmental cycle, the production of $\beta$-galactosidase by this strain being a lysis control which is of paramount importance in development conditions (O'Connor \& Zusman, 1988).

\section{Lack of secretion of AppA protein during submerged development of strain CM250}

Exponentially growing cells of strain CM250 in which, as shown previously (Letouvet-Pawlak et al., 1993), AppA protein is present in the periplasm were resuspended in MC7 buffer (submerged development conditions); no significant $\mathrm{pH} 2.5$ acid phosphatase activity was detected in the supernatant of cells undergoing submerged development for $20 \mathrm{~h}$ after the onset of starvation, in contrast to what happened when cells were resuspended in the CTT growth medium where AppA protein was secreted (Fig. 2a). Likewise, no extracellular proteases were assayable at $\mathrm{pH} 6.8$ (as well as at $\mathrm{pH} 9.6$ ) during the first $10-15 \mathrm{~h}$ of submerged development. The lack of extracellular AppA protein is therefore not due to proteolytic degradation.

In addition, the specific activity of both the phosphatase and $\beta$-galactosidase decreased when the cells were resuspended in MC7 buffer, whereas these activities remain constant under growth conditions (Fig. $2 b$ ). The synthesis of the two proteins therefore seems to be arrested during starvation; this result was obtained in either submerged or agitated conditions. The stronger decrease for the $\beta$-galactosidase than for the $\mathrm{pH} 2.5$ acid phosphatase could be attributed to different turn-over rates in the cytoplasm and periplasm. 

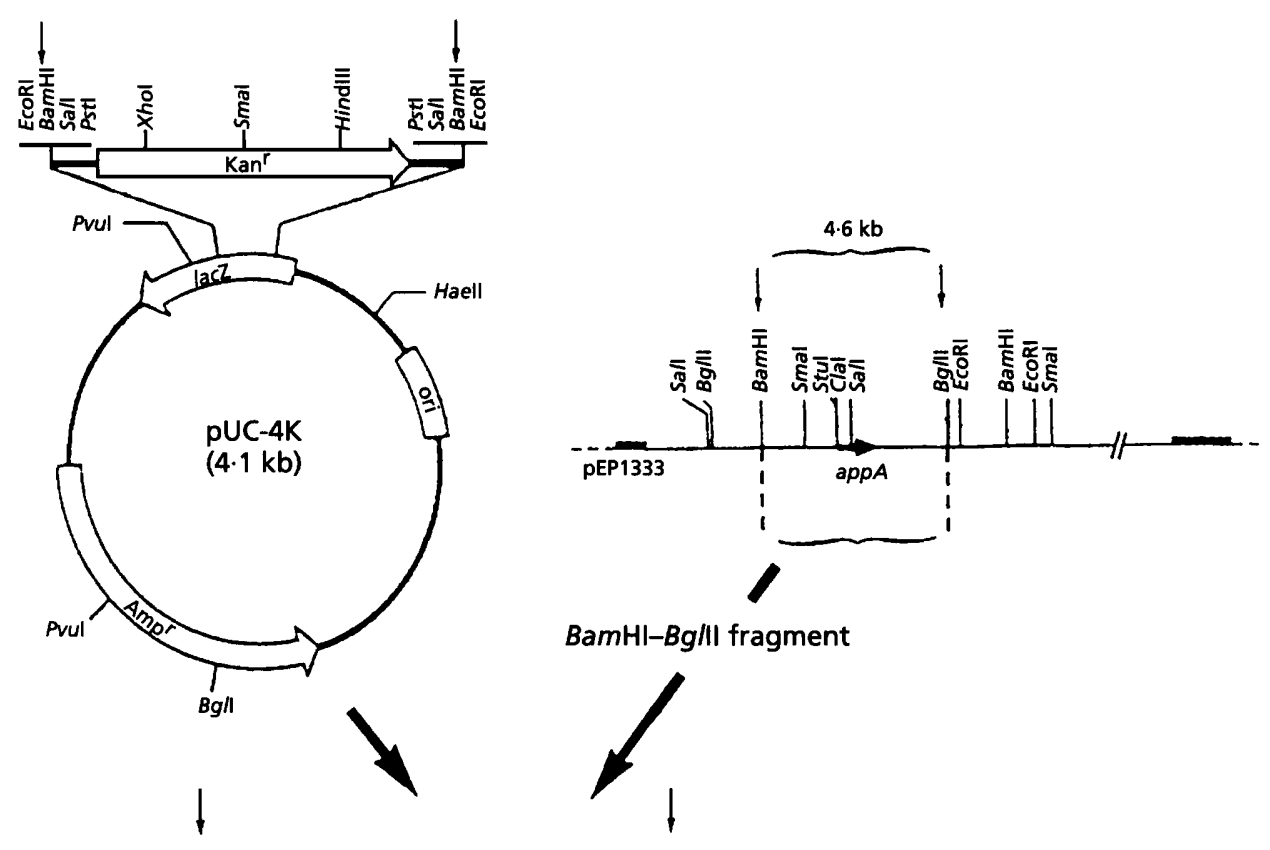

BamHI-Bg/lI fragment
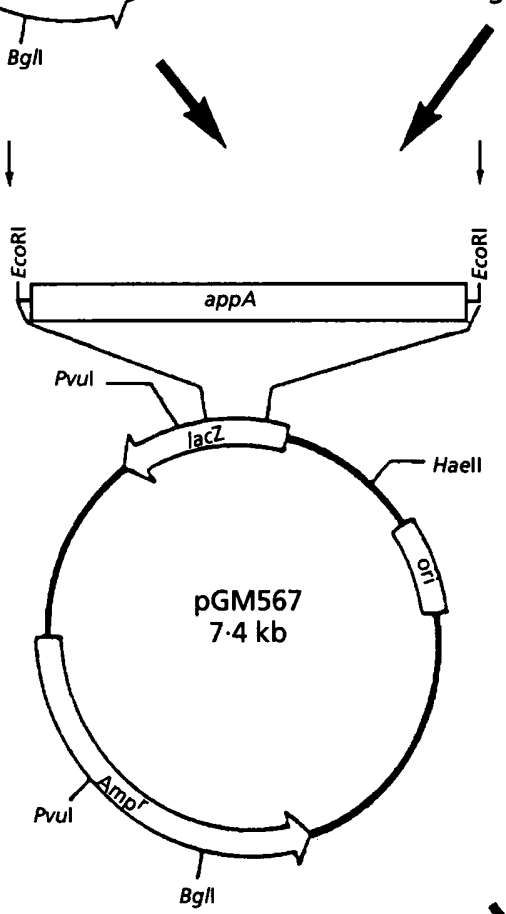

ECoRI-ECORI fragment $(4.6 \mathrm{~kb})$
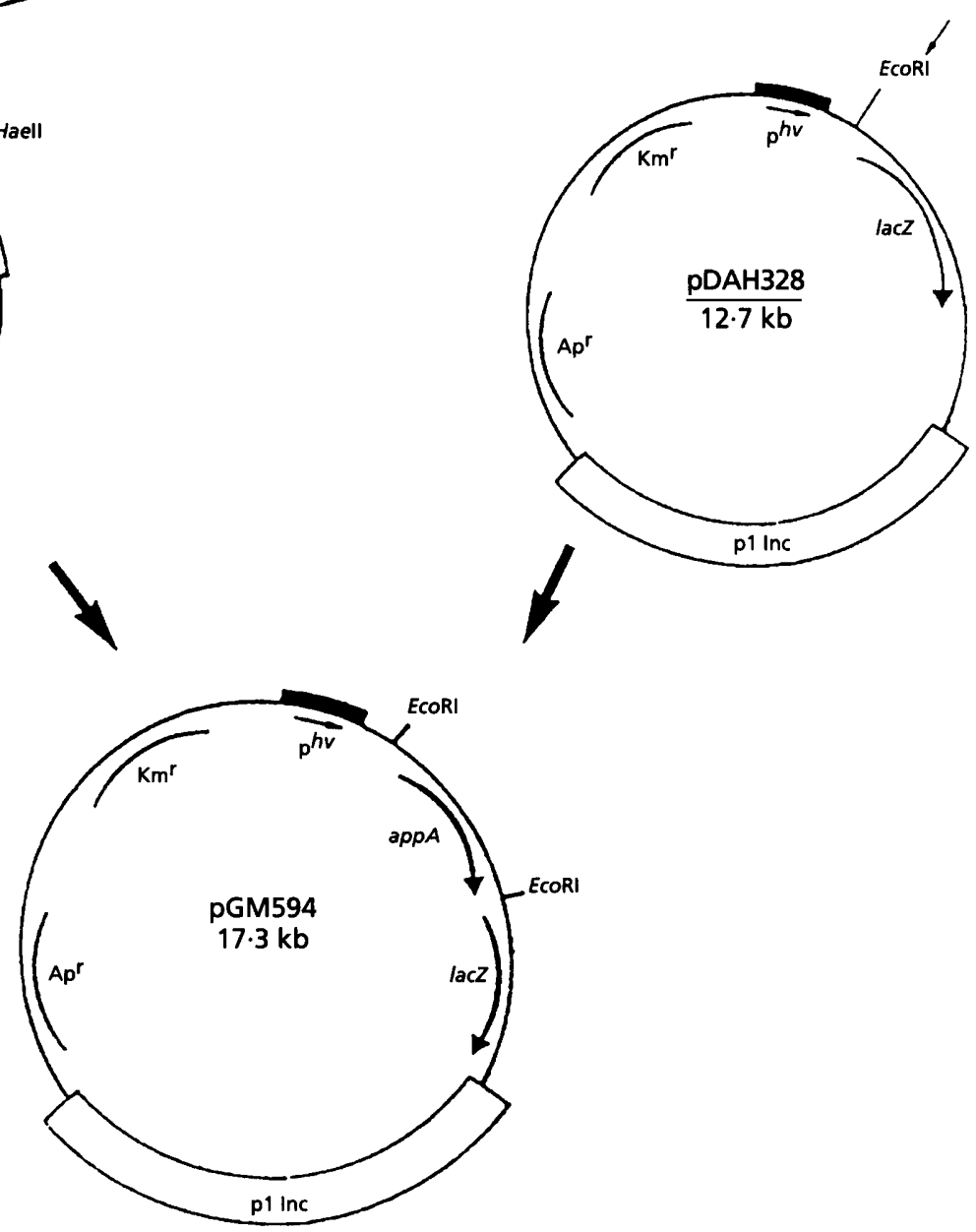

Fig. 1. Construction of plasmid pGM594. The pUC-4K plasmid, in which a gene conferring resistance to kanamycin is flanked by two symmetrical polylinkers, was used as an intermediate cloning vector. The BamHI-Bg/ll fragment containing the appA gene was first cloned in the pUC-4K plasmid digested by the restriction enzyme BamHI, in place of 

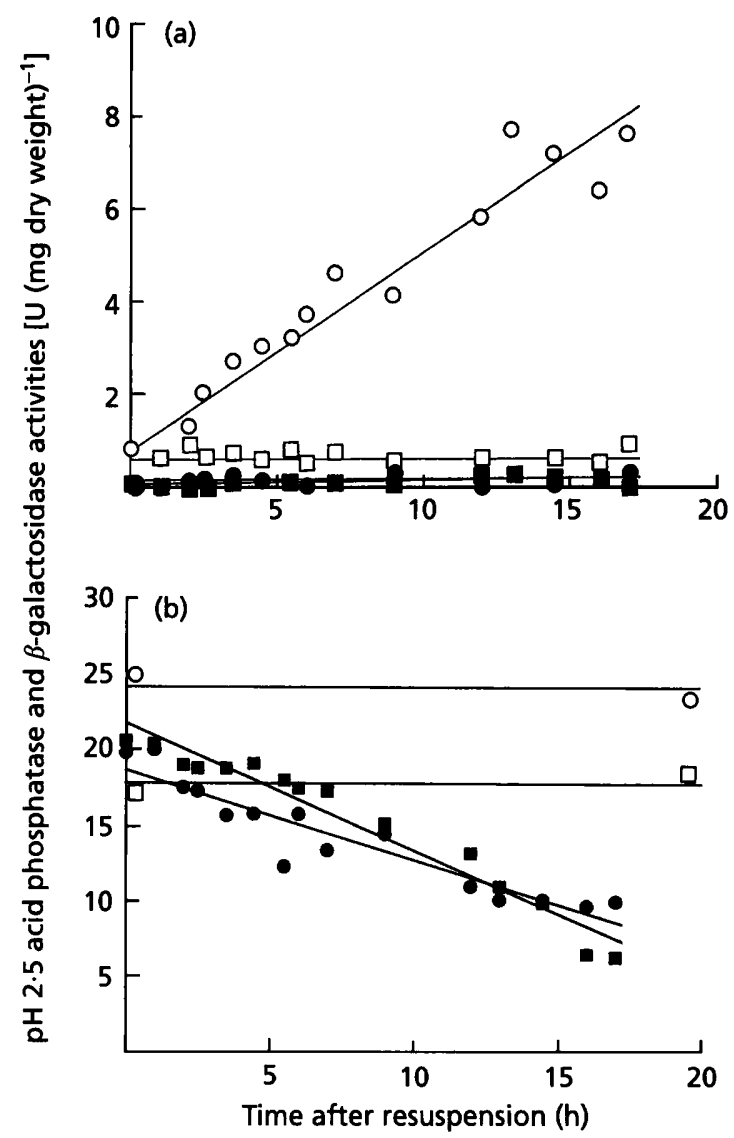

Fig. 2. $\mathrm{pH} 2.5$ acid phosphatase $(0, \bigcirc)$ and $\beta$-galactosidase $(\square, \square)$ production in supernatant (a) and cells (b) of $M$. xanthus strain CM250, after resuspension of exponentially growing cells in MC7 starvation buffer (closed symbols) or in CTा growth medium supplemented with kanamycin $\left(75 \mu \mathrm{g} \mathrm{ml}^{-1}\right.$ ) (open symbols). The enzymic activities in the cells (b) resuspended in CTT medium were $17.5 \pm 4 \cup \beta$-galactosidase (mg dry weight) ${ }^{-1}$ and $24.5 \pm 5 \cup$ AppA (mg dry weight $)^{-1}$. The experiment with MC7 buffer was performed three times under conditions of submerged development (described in Methods) and twice under agitated sporulation conditions with similar results. Enzyme activities were assayed as described in Methods and are expressed per $\mathrm{mg}$ dry weight owing to resumed growth; due to the difficulty in determining cell density under starvation conditions and to the fact that very little, if any, growth occurred, we used the initial density measured at the time of resuspension in MC7 buffer. Before resuspension, cells were grown in $C T$ medium supplemented with kanamycin $\left(75 \mu \mathrm{g} \mathrm{ml}^{-1}\right)$ to ensure selective pressure of the pGM594 plasmid.

\section{The lack of secretion of AppA protein is due to starvation}

This lack of secretion of AppA protein could be due to a starvation-induced modification of the outer envelope, or to arrest of protein accumulation in the periplasm, as a

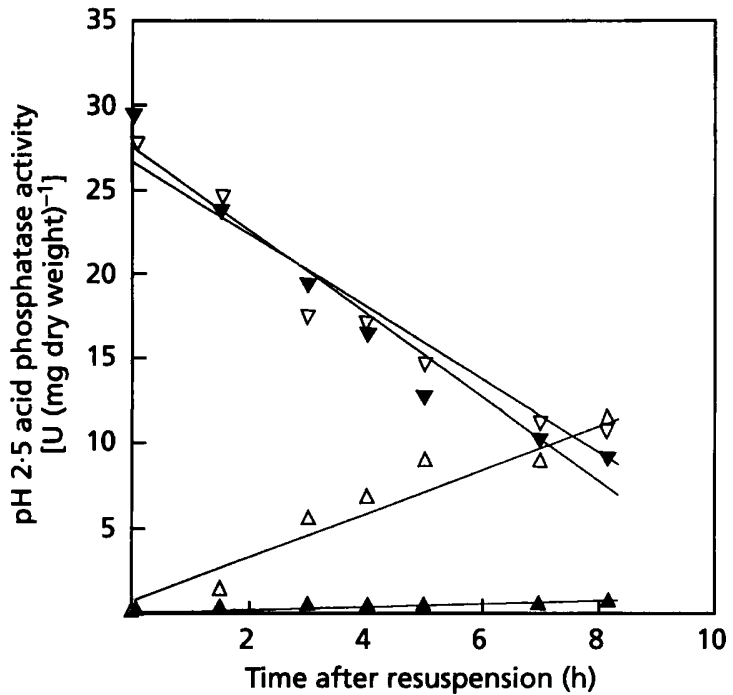

Fig. 3. $\mathrm{pH} 2 \cdot 5$ acid phosphatase production in cells $(\nabla, \nabla)$ and supernatant ( $\Delta, \Delta$ ) in $M$. xanthus strain CM243, after resuspension of IPTG-induced exponentially growing cells in MC7 starvation buffer (agitated conditions) (closed symbols) or in fresh $\mathrm{CTT}$ growth medium supplemented with oxytetracycline $\left(10 \mu \mathrm{g} \mathrm{ml}^{-1}\right)$ (open symbols). Before resuspension, cells were grown in CTT medium supplemented with oxytetracycline $\left(10 \mu \mathrm{g} \mathrm{m}^{-1}\right)$ to ensure selective pressure of the pGM589* plasmid, and with $10^{-3} \mathrm{M}$ IPTG to strongly induce expression of the appA gene. The $\mathrm{pH} 2.5$ acid phosphatase activity assays were performed as described in Methods.

consequence of synthesis arrest. To check the latter hypothesis, we used strain CM243 (Letouvet-Pawlak et al., 1993), in which the $a p p A$ gene was integrated in strain DK1622 under the control of the tac promoter; the expression of this gene is inducible by IPTG due to the presence of the lac $I^{\mathrm{q}}$ gene. To simulate the arrest of protein synthesis observed upon starvation and to study its effect on the phosphatase secretion, we induced $a p p A$ gene expression, then stopped this induction by suspension of the cells in an IPTG-free medium. We compared the secretion of the AppA protein after resuspension of the fully IPTG-induced cells of strain CM243 in fresh CTT medium or in MC7 buffer (agitated conditions) without IPTG (arrest of induction). As seen in Fig. 3, the AppA specific activity in the periplasm decreased under both conditions; however, while secretion of AppA occurred when cells were resuspended in CTT growth medium, no such secretion was observed in the MC7 starvation medium. This result suggests that the arrest of AppA protein synthesis (and export) is not the cause of the absence of secretion of this protein in the starvation medium. However, some background AppA protein synthesis might still occur under these conditions in CTT medium. 


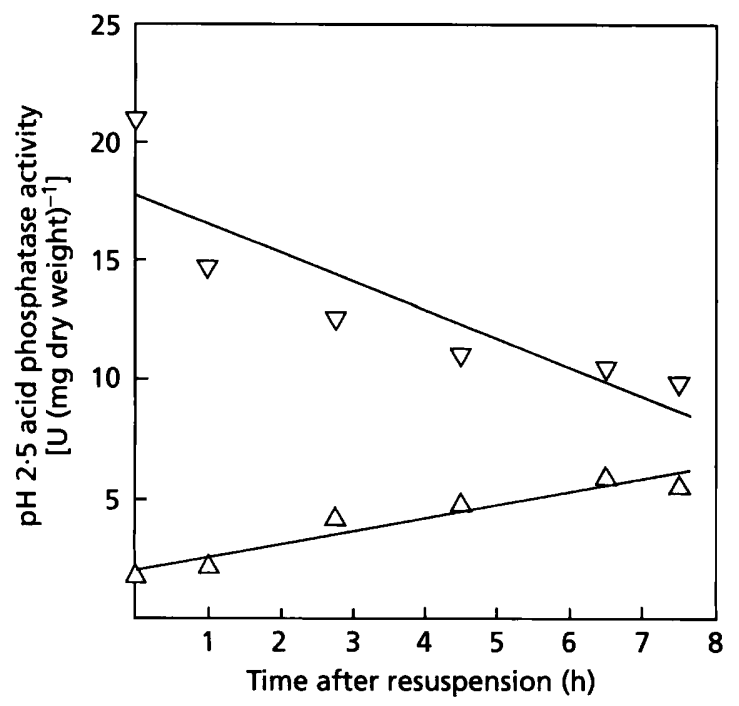

Fig. 4. $\mathrm{pH} 2 \cdot 5$ acid phosphatase production in cells $(\nabla)$ and supernatant $(\triangle)$ of $M$. xanthus strain CM250, after resuspension of exponentially growing cells in fresh $C T$ growth medium supplemented with kanamycin $\left(75 \mu \mathrm{g} \mathrm{ml}^{-1}\right)$ and chloramphenicol $\left(7.5 \mu \mathrm{g} \mathrm{ml}^{-1}\right)$. Prior to resuspension, cells were grown in $C \pi$ medium supplemented with kanamycin $\left(75 \mu \mathrm{g} \mathrm{ml}^{-1}\right)$. The $\mathrm{pH} 2.5$ acid phosphatase activity assays were performed as described in Methods.

To confirm that the arrest of protein synthesis has no effect on secretion, we carried out a second experiment using the antibiotic chloramphenicol which inhibits protein translation. We used the $M$. xantbus strain CM250 (DK1622::pGM594) and studied AppA protein secretion kinetics after resuspension of the cells in fresh CTT growth medium supplemented with $7.5 \mu \mathrm{g}$ chloramphenicol $\mathrm{ml}^{-1}$. Under these conditions, growth was arrested, showing that protein translation was stopped. As shown in Fig. 4, the phosphatase was still secreted, whereas the periplasmic content decreased, as observed in the previous experiment with strain CM243 in CTT medium (see above). Thus, the lack of secretion observed in MC7 buffer is indeed a direct starvation response.

To determine whether this lack of secretion was due to the onset of the developmental cycle or to the starvation conditions, as could be suspected from the arrest of synthesis of the two foreign proteins, we checked different starvation conditions and different strains. No AppA protein secretion was observed in agitated sporulation medium (Fig. 2a). This observation did not depend on the $\mathrm{pH}$ of the sporulation buffer, nor on the presence of $\mathrm{Ca}^{2+}$ ions, since no extracellular AppA protein was detected when cells were resuspended in TT buffer $(\mathrm{pH} 7 \cdot 6)$ with or without added $\mathrm{CaCl}_{2}$. Neither did the presence of $1 \mathrm{mM} \mathrm{CaCl} 2$ in the CTT growth medium alter the secretion of the foreign protein. Moreover, the lack of secretion did not depend on the ability of the cells to undergo development since it was also impossible to detect the phosphatase in the supernatant of starved cells of strain CM2216 (DZ1::pGM594), although DZ1 is a non-motile, non-developing, non-sporulating mutant
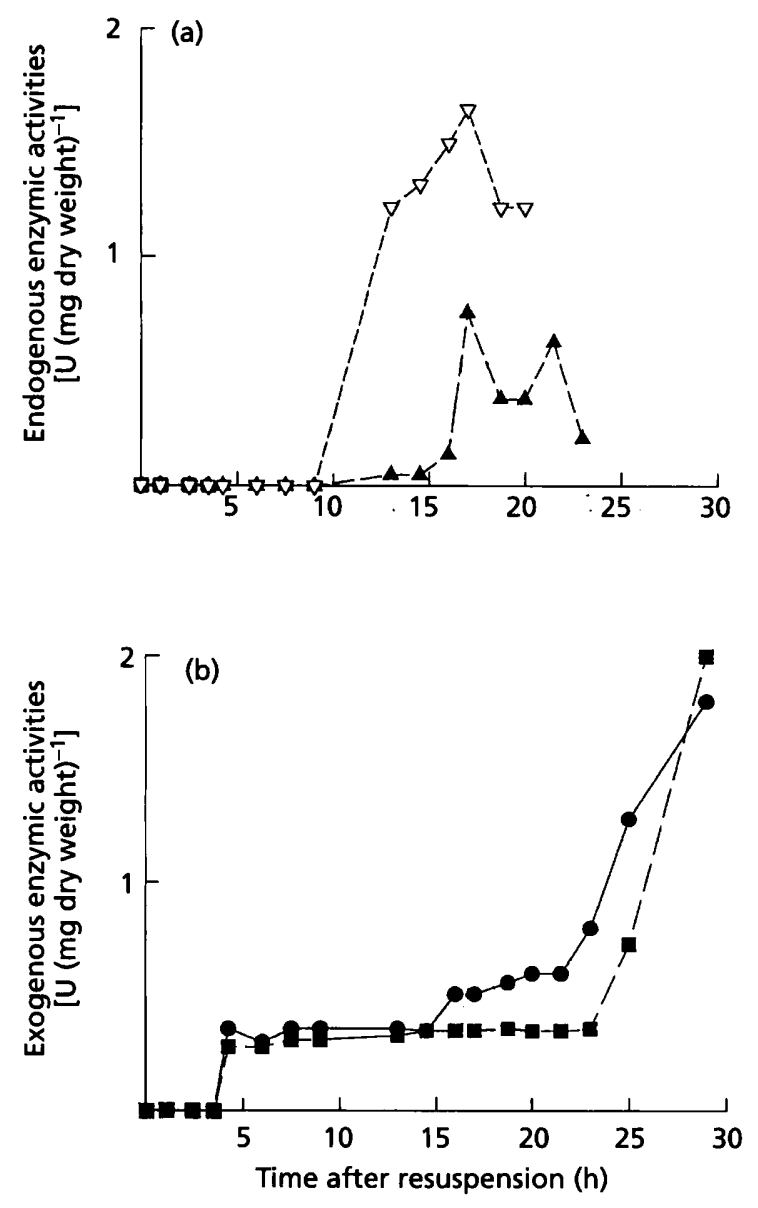

Fig. 5. (a) Native protein secretion $(\nabla, M C P$; $\Delta$, alkaline protease) during submerged development of strain CM250. No MCP and alkaline protease activities were found inside the cells as most of the native proteins are secreted in $M$. xanthus (Guespin-Michel et al., 1993). (b) Extracellular pH 2.5 acid phosphatase activity (O) and evidence for cell lysis (extracellular $\beta$-galactosidase activity, $\square$ ) during submerged development of strain CM250. The cell contents at $t=0$ were $24.5 \pm 5 \mathrm{U}$ AppA (mg dry weight) $)^{-1}$ and $17.5 \pm 4 \mathrm{U} \beta-$ galactosidase (mg dry weight) ${ }^{-1}$. About $1 \%$ of cell lysis is sometimes observed in the first few hours of the experiment. Culture conditions are as described in the legend of Fig. 2(a). Enzymic assays were performed as described in Methods.

(Zusman et al., 1978). Under all these conditions, neither secretion of AppA protein nor the cellular accumulation of this protein or of $\beta$-galactosidase was observed.

\section{Native protein secretion does occur in strain CM250 during submerged development}

Since the presence of the integrated plasmid pGM594 seems to greatly decrease the growth rate and development kinetics of strain CM250, we wanted to make sure that the secretion of native proteins was not impaired in this strain during submerged development. Fig. 5(a) shows that $\mathrm{MCP}$ and alkaline proteases are indeed secreted under these conditions, when no extracellular AppA protein could be detected (Fig. 5b). The appearance of 
this latter protein in the cell supernatant (around $25 \mathrm{~h}$ ) was coincident with the appearance of the cytoplasmic $\beta$ galactosidase in the medium, showing that no secretion of the AppA protein occurred prior to cell lysis under the starvation conditions (Fig. 5b).

\section{DISCUSSION}

One main drawback to studying protein secretion during the developmental cycle in $M$. xanthus is the existence of cell lysis (O'Connor \& Zusman, 1988; Guespin-Michel $e t$ al., 1993). The use of a strain that produces both the cytoplasmic $\beta$-galactosidase and the partially periplasmic/ partially secreted E. coli $\mathrm{pH} 2.5$ acid phosphatase ensured that secretion would not be mistaken with cell lysis. Indeed, after $25 \mathrm{~h}$ of starvation, the appearance of $\beta$ galactosidase in the medium gave an indication of cell lysis which forbade any study of secretion of AppA protein henceforth.

The important result is that no foreign protein is secreted under conditions of submerged development at a time when the developmentally regulated protein MCP as well as alkaline proteases appear in the extracellular medium. This shows that although the diffusion of AppA protein through the outer envelopes is not possible under these conditions, protein MCP and the other extracellular proteins produced early during the development (Plamann et al., 1992) are readily secreted. In a previous study, we postulated that extracellular protein secretion during vegetative growth of $M$. xanthus occurs at least in part by the diffusion pathway of AppA protein (LetouvetPawlak et al., 1993). The present results show that, upon starvation, the AppA protein does not reflect the behaviour of native secreted proteins; these latter proteins must therefore follow a different secretion route, which indicates the existence of at least another mode of protein secretion during development. (Although less likely, one cannot, however, exclude that the decrease of permeability of the envelopes to foreign protein, induced by the $\mathrm{Exc}^{+/-}$ mutation, may not be the cause of the decrease of native protein secretion in this mutant.)

Our results suggest different events arise immediately upon starvation: arrest of synthesis of two foreign proteins and arrest of protein diffusion through the outer envelope. The first event is very likely related to the stringent response, since it depends neither on the starvation conditions nor on the ability of the strain to undergo development. We are tempted to suppose that the arrest of synthesis is due to an arrest of transcription, which would be in agreement with studies on the regulation of gene expression during $M$. xantbus development showing a control at a transcriptional level (Downard \& Kroos, 1993). However, mRNA stability or protein translation could be altered as well.

The second event, i.e. the arrest of protein diffusion, is not due to the mere lack of accumulation of the protein in the periplasm, and therefore suggests a rapid and drastic modification in the structure of the outer envelopes, most likely of the outer membrane, and decrease of their permeability. This modification is not due to the arrest of synthesis of one or several proteins from these envelopes because of the rapidity of the event on one hand, and, on the other hand, of the maintenance of secretion in CTT medium supplemented with chloramphenicol; this latter result actually shows that the inhibition of protein synthesis for a few hours does not alter the permeability of outer envelopes.

The permeability of the outer membrane is generally studied by using small molecules such as $\beta$-lactam antibiotics that either penetrate through the porins or diffuse through the lipid bilayer (Nikaido \& Vaara, 1985). Thus, a starvation-induced modification of the fatty acid composition of the outer membrane was reported in $E$. coli to cause a decrease in the permeability of this layer (Cronan, 1968). However, most biological membranes are strictly impermeable to macromolecules such as proteins and the molecular basis of this permeability in $M$. xantbus is still obscure.

\section{ACKNOWLEDGEMENTS}

We thank Dr D. A. Hodgson for kindly providing plasmid pDAH328 and bacteriophage P1, and Dr P. L. Boquet for the gift of plasmid pEP1333. We thank N. Cariou for careful technical assistance.

\section{REFERENCES}

Breton, A. \& Guespin-Michel, J. F. (1987). E. coli $\mathrm{pH} 2.5$ acid phosphatase and $\beta$-lactamase TEM-2 are secreted into the medium by Myxococcus xantbus. FEMS Microbiol Lett 40, 183-188.

Breton, A. M., Younes, G., VanGijsegen, F. \& Guespin-Michel, J. F. (1986). Expression in Myxococcus xanthus of foreign genes coding for secreted pectate lyases of Erwinia chrysanthemi. J Biotechnol 4, 303-311.

Bretscher, A. P. \& Kaiser, D. (1978). Nutrition of Myxococcus xanthus, a fruiting myxobacterium. $J$ Bacteriol 133, 763-768.

Casadaban, M. \& Cohen, S. N. (1980). Analysis of gene control signals by DNA fusion cloning in Escherichia coli. J Mol Biol 138, 179-207.

Cronan, J. E. (1968). Phospholipid alterations during growth of Escherichia coli. J Bacteriol 95, 2054-2061.

Dagert, M. \& Ehrlich, S. D. (1974). Prolonged incubation in calcium chloride improves competence of Escherichia coli cells. Gene 6, 23-28.

Dassa, E. \& Boquet, P. L. (1981). $\exp A$ : a conditional mutation affecting the expression of a group of exported proteins in Escherichia coli K-12. Mol \& Gen Genet 181, 192-200.

Dassa, J., Marck, C. \& Boquet, P. L. (1990). The complete nucleotide sequence of the Escherichia coli gene $a p p A$ reveals significant homology between $\mathrm{pH} 2 \cdot 5$ acid phosphatase and glucose-1-phosphatase. J Bacteriol 172, 5497-5500.

Douillard, D. \& Ribadeau-Dumas, B. (1970). Détermination avec la K-caseine de l'activité protéolytique de la présure, de la pepsine de porc et des pepsines bovines. Bull Svc Cbim Biol 52, 1429-1445.

Downard, J. \& Kroos, L. (1993). Transcriptional regulation of developmental gene expression in Myxococcus xantbus. In Myxobacteria II, pp. 183-199. Edited by M. Dworking \& D. Kaiser. Washington, DC: American Society for Microbiology.

Guespin-Michel, J. F., Letouvet-Pawlak, B. \& Petit, F. (1993). Protein secretion in myxobacteria. In Myxobacteria II, pp. 235-255. 
Edited by M. Dworkin \& D. Kaiser. Washington, DC: American Society for Microbiology.

Hanahan, D. (1983). Studies on transformation of Escherichia coli with plasmids. $J$ Mol Biol 166, 557-580.

He, S. Y., Lindeberg, M., Chatterjee, A. K. \& Collmer, A. (1991). Cloned Erwinia chrysanthemi out genes enable Eschericbia coli to selectively secrete a diverse family of heterologous proteins to its milieu. Proc Natl Acad Sci US A 88, 1079-1083.

Hodgson, D. A. (1987). Light-inducible promoter. International Patent Application No. PCT/GB87/0040; New British Patent Application No. 8615263.

Hodgson, D. A. (1993). Light-induced carotenogenesis in Myxococcus xanthus: genetic analysis of the carR region. Mol Microbiol 7, 471-488.

Holmes, D. S. \& Quigley, M. (1981). A rapid boiling method for the preparation of bacterial plasmids. Anal Biochem 114, 193-197.

Kaiser, D. (1979). Social gliding is correlated with the presence of pili in Myxococcus xantbus. Proc Natl Acad Sci US A 76, 5952-5956.

Kaiser, D. (1989). Multicellular development in myxobacteria. In Genetics of Bacterial Diversity, pp. 243-246. Edited by D. A. Hopwood \& K. F. Chater. San Diego: Academic Press.

Kuner, J. H. \& Kaiser, D. (1982). Fruiting body morphogenesis in submerged cultures of Myxococcus xanthus. J Bacteriol 151, 458-461.

Kuspa, A. L. \& Kaiser, D. (1989). Genes required for developmental signalling in Myxococcus xanthus: three asg loci. J Bacteriol 171, $2762-2772$

Letouvet-Pawlak, B., Monnier, C., Barray, S., Hodgson, D. A. \& Guespin-Michel, J. F. (1990). Comparison of $\beta$-galactosidase production by two inducible promoters in Myxococcus xanthus. Res Microbiol 141, 425-435.

Letouvet-Pawlak, B., Barray, S., Laval-Favre, K. \& Guespin-Michel, J. F. (1993). Kinetics of secretion of recombinant acid phosphatase by Myxococcus xanthus: a sensitive probe for the assay of protein translocation through the envelopes. $J$ Gen Microbiol 139, 3243-3252.

Masson, P. J. \& Guespin-Michel, J. F. (1988). An extracellular blood-anticoagulant glycopeptide produced exclusively during vegetative growth by Myxococcus xanthus and other myxobacteria is not co-regulated with other extracellular macromolecules. $J$ Gen Microbiol 134, 801-806.

Miller, J. H. (1972). Experiments in Molecular Genetics, pp. 352-355. Cold Spring Harbor, NY: Cold Spring Harbor Laboratory.
Millet, J. (1970). Characterization of proteinases excreted by Bacillus subtilis Marburg strain during sporulation. J Appl Bacteriol 33, 207-219.

Nicaud, J. M., Breton, A., Younes, G. \& Guespin-Michel, J. F. (1984). Mutants of Myxococcus xanthus impaired in protein secretion: an approach to study of a secretory mechanism. Appl Micrabiol Biotechnol 20, 344-350.

Nikaido, H. \& Vaara, M. (1985). Molecular basis of bacterial outer membrane permeability. Microbiol Rev 49, 1-32.

O'Connor, K. A. \& Zusman, D. R. (1988). Reexamination of the role of autolysis in the development of Myxococcus xanthus. J Bacteriol 170, 4103-4112.

Petit, F. \& Guespin-Michel, J. F. (1992). Production of an extracellular milk-clotting activity during development in Myxococcus xanthus. J Bacteriol 174, 5136-5140.

Petit, F., Merah, M., Monnier, C. \& Guespin-Michel, J. F. (1993). Mutations in two new loci that impair both extracellular protein production and development in Myxococcus xanthus. J Bacteriol 175, 4239-4244.

Plamann, L., Kuspa, A. \& Kaiser, D. (1992). Proteins that rescue Asignal-defective mutants of Myxococcus xanthus. J Bacteriol 174, 3311-3318.

Pugsley, A. P. (1993). The complete general secretory pathway in Gram-negative bacteria. Microbiol Rev 57, 50-108.

Salmond, G. P. C. \& Reeves, P. J. (1993). Membrane traffic wardens and protein secretion in Gram-negative bacteria. Trends Biochem Sci 18, 7-12.

Shimkets, L. J. (1990). Social and developmental biology of the myxobacteria. Microbiol Rev 54, 473-501.

Shimkets, L. J., Gill, R. E. \& Kaiser, D. (1983). Developmental cell interactions in Myxococcus xanthus and the spoC locus. Proc Natl Acad Sci US A 80, 1406-1410.

Vieira, J. \& Messing, J. (1982). The pUC plasmids, an M13mp7derived system for insertion mutagenesis and sequencing with synthetic universal primers. Gene 19, 259-268.

Zusman, D. R., Kotoski, D. M. \& Cumsky, M. (1978). Chromosome replication in Myxococcus xanthus. J Bacteriol 133, 122-129.

Received 31 March 1995; revised 9 August 1995; accepted 23 August 1995. 